\title{
X-linked spastic paraplegia type 34
}

INSERM

\section{Source}

INSERM. (1999). Orphanet: an online rare disease and orphan drug data base. $\underline{X \text {-linked }}$ spastic paraplegia type 34. ORPHA:171607

X-linked spastic paraplegia type 34 is a pure form of hereditary spastic paraplegia characterized by late childhood- to early adulthood-onset of slowly progressive spastic paraplegia with spastic gait and lower limb hyperreflexia, brisk tendon reflexes and ankle clonus. Lower limb pain and reduced lower limb vibratory sense is also reported in some older adult patients. 